\title{
Grain size distribution of road-deposited sediment and its contribution to heavy metal pollution in urban runoff in Beijing, China
}

\author{
Hongtao Zhao, Xuyong Li*, Xiaomei Wang, Di Tian \\ State Key Laboratory of Urban and Regional Ecology, Research Center for Eco-Environmental Sciences, Chinese Academy of Sciences, Shuangqing Road 18, Beijing 100085, China
}

\section{A R T I C L E I N F O}

\section{Article history:}

Received 2 April 2010

Received in revised form 10 June 2010

Accepted 3 July 2010

Available online 31 July 2010

\section{Keywords:}

Road-deposited sediment

Grain size distribution

Heavy metal loads

Urban runoff

Urban land use

\begin{abstract}
A B S T R A C T
Pollutant washoff from road-deposited sediment (RDS) is an increasing problem associated with the rapid urbanization of China that results in urban non-point source pollution. Here, we analyzed the RDS grain size distribution and its potential impact on heavy metal pollution in urban runoff from impervious surfaces of urban villages, colleges and residences, and main traffic roads in the Haidian District, Beijing, China. RDS with smaller grain size had a higher metal concentration. Specifically, particles with the smallest grain size $(<44 \mu \mathrm{m})$ had the highest metal concentration in most areas (unit: $\mathrm{mg} / \mathrm{kg}$ ): $\mathrm{Cd}$ 0.28-1.31, Cr 57.9-154, Cu 68.1-142, Ni 25.8-78.0, Pb 73.1-222 and Zn 264-664. Particles with smaller grain size $(<250 \mu \mathrm{m})$ contributed more than $80 \%$ of the total metal loads in RDS washoff, while suspended solids with a grain size $<44 \mu \mathrm{m}$ in runoff water accounted for greater than $70 \%$ of the metal mass in the total suspended solids (TSS). The heavy metal content in the TSS was $2.21-6.52 \%$ of that in the RDS. These findings will facilitate our understanding of the importance of RDS grain size distribution in heavy metal pollution caused by urban storm runoff.
\end{abstract}

(c) 2010 Elsevier B.V. All rights reserved.

\section{Introduction}

Due to China's rapid urban population growth and industrialization, urban runoff with contaminated road-deposited sediment (RDS) has become an increasingly serious problem [1]. RDS is an important environmental medium due to its atmospheric resuspension and because it is present in storm runoff [2]. RDS is the sink and source of metals and other contaminants on impervious surfaces in urban environments [3], and it often contains elevated concentrations of toxic metals [4]. During rainfall, RDS is transported into the receiving waters, where it has a marked effect on water quality and aquatic biota [5]. Urban storm runoff has been deemed one of the leading sources of water quality impairment for rivers, lakes and estuaries [6]. It is also well known that urban storm runoff is much more difficult to control due the random nature of rainfall and uncertainty of the pollution source [7].

The grain size distribution of RDS is a particularly important factor because it determines the mobility of the particles and their associated pollutant concentrations [8-10]. The behavior of RDS in runoff depends on its grain size distribution [11,12]. Furthermore, smaller particles have lower densities [1], greater surface area per volume unit and higher organic matter contents [13,14]. For most pollutants, higher concentrations are found on smaller RDS [15-17]. Street surfaces are both sources of urban runoff pol-

\footnotetext{
* Corresponding author. Tel.: +86 10 62849428; fax: +86 1062849428 .

E-mail address: xyli@rcees.ac.cn (X. Li).
}

lutants and pathways for the transport of pollutants [18]. Street sweepers play an important role in removing litter and debris, but are relatively ineffective at removing smaller particles [19]. Indeed, many studies have shown that the efficiency of conventional street sweeping decreases with grain size [20,21]. Hence, smaller particles remain after street sweeping and are incorporated into stormwater runoff [22].

The amount, particulate size and particulate mobility of RDS are critical to assessment of the role of RDS in heavy metal pollution in urban runoff. Most previous studies have focused on the pollutant distribution in different size RDS and the concentration or transport of pollutants in runoff water separately [7,23-26]. Few studies have investigated the grain size distribution in RDS and suspended solids in stormwater runoff simultaneously $[8,27]$. A previous study demonstrated the importance of grain size for modeling sedimentassociated transport from urban road surfaces [2]. The results of these previous studies have indicated that there is clearly a need to link the amount and grain size distribution of RDS with suspended solids in stormwater runoff so that we can better understand how RDS affects heavy metal pollution through urban runoff.

Like most big cities, Beijing has experienced a rapid expansion of impervious surface due to the migration of people from rural to urban areas in the last decade. In this study, we measured the amount, particulate size, and particulate mobility of RDS and heavy metal concentrations in runoff water from impervious surfaces of different land uses in the Haidian District of Beijing. Specifically, the following aspects were addressed in this paper: (1) What is the critical grain size associated with heavy metal pollutants in RDS? (2) 


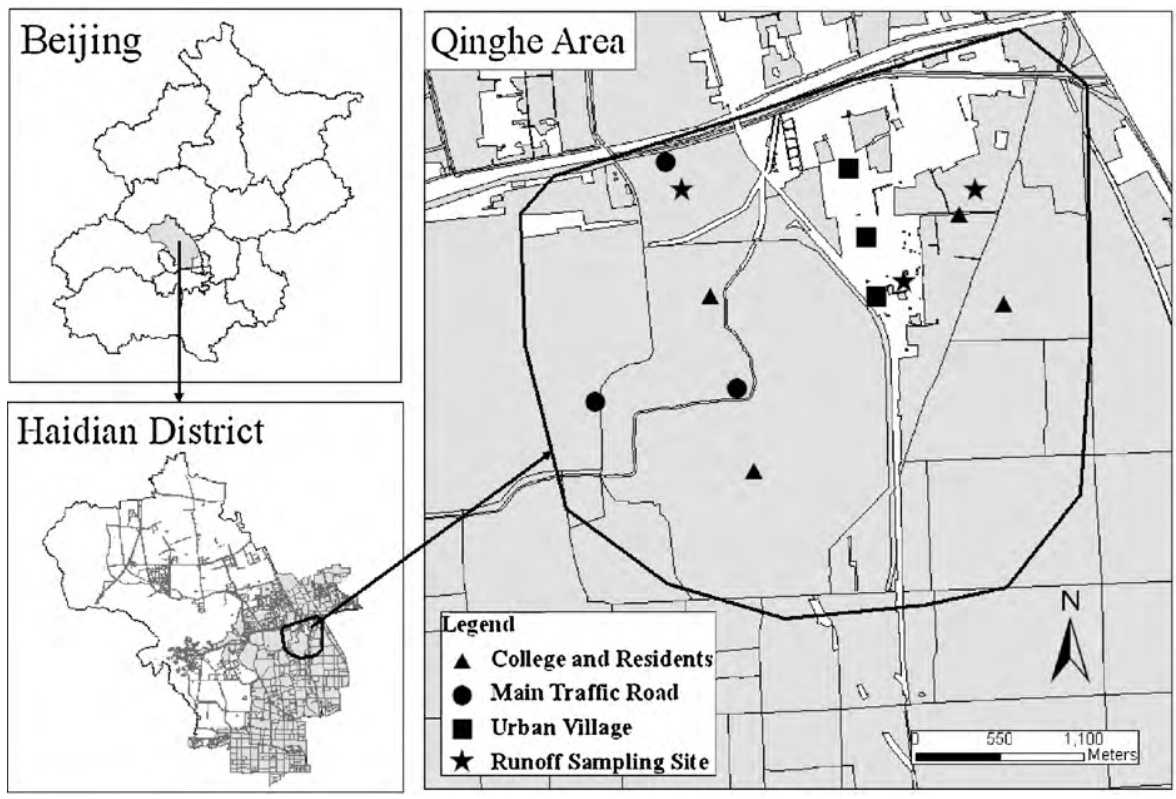

Fig. 1. Study area and sampling site locations in the Qinghe area of the Haidian District, Beijing, China.

How do the amount and grain size of RDS affect suspended solids and heavy metal concentrations in urban runoff? (3) What is the role of urban land use types in RDS and what is their contribution to heavy metal pollution in urban runoff?

\section{Materials and methods}

\subsection{Study site description}

Haidian, which is one of eight districts in the urban area of Beijing, China, is located in the northwest portion of the city. The mean annual temperature of Haidian is $14.0^{\circ} \mathrm{C}$ and the average annual rainfall is $570 \mathrm{~mm}$. The district has an area of $430 \mathrm{~km}^{2}$, a population of 2.81 million and contains more than 80 higher education and 213 research institutions. In addition, most farm villages in the region are rapidly being converted into urban villages. Overall, colleges and residences, urban villages and main traffic roads are the three typical impervious land use types in Haidian District. The important factors affecting RDS amount and contaminant concentration of RDS in our study areas include impervious surface condition, street sweeping manner and frequency, and traffic intensity. Colleges and residences have relatively smooth and less damaged impervious surface, regularly daily hand-sweeping or mechanical sweeping, lower traffic intensity; urban villages have heavily damaged imperious surface, rarely street sweeping, and medium level of traffic intensity; main traffic roads have less damaged impervious surface, regularly daily mechanical sweeping, and higher traffic intensity. The streets in the region are hand-swept daily with straw brooms in the colleges and residences, with the exception of Tsinghua University, where the streets are swept with a mechanical sweeper. The roads in the urban villages are rarely swept, while mechanical sweepers are used to clean the main traffic roads. In our study area, runoff water finally enters the Qinghe River through the city rainfall drainage pipe system.

\subsection{Sample collection and grain size fractionating}

\subsubsection{RDS sample collection and grain size fraction}

We collected RDS samples using a domestic vacuum cleaner during June 9-10, 2009. The RDS sampling sites were distributed among the following land use types: three in urban village roads, four in residential and college avenues, and three on main traffic roads (Fig. 1). We had three duplicate sampling points at each sampling site. The sites on main traffic roads and college avenues were paved with asphalt, while the other sites were paved with concrete. Sampling area was from the central line to the curb of the road and the size of area was measured by the ruler. We measured total RDS mass weight at each sampling area. We took about $0.8-1.5 \mathrm{~kg}$ of RDS sample at each sampling point. Polyester sieves were used for grain size fractionation.

Samples were sorted into grain size fractions of $<44$, $44-62,62-105,105-149,149-250,250-450,450-1000$ and $1000-2000 \mu \mathrm{m}$. Heavy metals were analyzed for each grain size fraction. In the field of sedimentology, grain size $<63 \mu \mathrm{m}$, 63-125 $\mu \mathrm{m}, \quad 125-250 \mu \mathrm{m}, \quad 250-500 \mu \mathrm{m}, \quad 500-1000 \mu \mathrm{m}$, and $1000-2000 \mu \mathrm{m}$ is typically referred to as silt and clay, very fine sand, fine sand, medium sand, coarse sand, and very coarse sand, respectively [2].

\subsubsection{Runoff water sample collection}

Runoff water samples were collected from three different land use impervious surfaces: Qianbajia (urban village), Xiangbaiqiqiao (main traffic road), and Jingshiyuan (residential and college avenues). In our study area, runoff water finally enters the Qinghe River through the city rainfall drainage pipe system. The samples were taken during two rainfall events, $27 \mathrm{~mm}$ rainfall for 1.8 h on June 16,2009 , and $44 \mathrm{~mm}$ rainfall for 2.9 h on June $18,2009$. We collected runoff water samples manually at each site at 5-min intervals during the first 15 min of the rainfall event; after that the samples were collected at 10-min intervals until there was no more runoff. We collected 12 and 19 water samples at each site during their two rain events on June 16 and 18, 2009, respectively. The runoff volume was measured using calibrated polythene barrels with a volume of $20 \mathrm{~L}$ for higher volumes and $5 \mathrm{~L}$ barrels for lower volumes during rainfall events. In addition, water samples were collected using plastic bottles and then analyzed in the laboratory within 5 days of the sampling date.

\subsubsection{Estimation of heavy metal loads in RDS}

To determine the contribution of particles with different grain sizes to the overall contamination of the RDS, we computed the pollutant load percentage for individual RDS samples. We considered 
the heavy metal concentration of each grain size fraction and their mass weight proportions in the calculation. The $\mathrm{GSF}_{\text {Load }}$ (load on a grain size fraction) was computed using the following equation $[2,7]$ :

$$
\mathrm{GSF}_{\text {Load }}=\frac{C_{i} \times \mathrm{GS}_{i}}{\sum_{i=1}^{m} C_{i} \times \mathrm{GS}_{i}}
$$

where $C_{i}$ is the heavy metal concentration in the RDS particle with a grain size fraction of $i$; $\mathrm{GS}_{i}$ is the mass weight percentage of the size fraction, $i$; and $m$ is the number of grain size fractions.

\subsubsection{Estimation of heavy metal loads in runoff}

We applied the event mean concentration (EMC) to estimate heavy metal loads in runoff. EMC is the flow-weighted average of the constituent concentrations [28]:

$\mathrm{EMC}=\frac{\int_{0}^{1} C(t) \times Q(t) d t}{\int_{0}^{1} Q(t) d t}$

where EMC is event mean concentration $(\mathrm{mg} / \mathrm{L}) ; C(t)$ is the heavy metal concentration $(\mathrm{mg} / \mathrm{L})$ in runoff water at each sampling time; $Q(t)$ is runoff flow rate at each sampling time $\left(\mathrm{m}^{3} / \mathrm{min}\right)$.

\subsection{Analytical methods}

We analyzed six heavy metal elements ( $\mathrm{Cd}, \mathrm{Cr}, \mathrm{Cu}, \mathrm{Ni}, \mathrm{Pb}$ and $\mathrm{Zn}$ ) for all RDS and runoff samples using the standard methods [29]. RDS samples were digested with $\mathrm{HF}-\mathrm{HClO}_{4}$ [30]. GBW07401(GSS-1) and GBW07402(GSS-2) are the certified reference materials (CRMs) for soil certified by General Administration of Quality Supervision, Inspection and Quarantine of the People's Republic of China and they are used as the CRMs for digestion of RDS.

Runoff water samples were filtered through pre-weighed $0.45 \mu \mathrm{m}$ Millipore filter paper and then adjusted to $\mathrm{pH} \leq 2$ by the addition of nitric acid. Solid particles remaining in the filter paper were then dried and re-weighed to quantify the total suspended solids (TSS). Next, we applied concentrated $\mathrm{HNO}_{3}$ to digest the unfiltered runoff water samples, after which the solutions were used to measure the total metals. The particulate metal concentrations were determined as the difference between the total metal in the unfiltered runoff water and the metal concentration in the filtrate. We measured blanks for each batch of samples using the same procedure that was used for filtrate samples.

All solutions were stored at $4{ }^{\circ} \mathrm{C}$ prior to analysis. The concentrations of $\mathrm{Cr}, \mathrm{Cu}, \mathrm{Ni}, \mathrm{Pb}$ and $\mathrm{Zn}$ were determined using a Perkin-Elmer Elan 6000 ICP-OES. The concentrations of Cd were determined using an Agilent 7500a ICP-MS (Agilent Technologies, USA). The grain size distribution of suspended solids in runoff water was measured using a Mastersize 2000 laser particle size analyzer (Malvern Instruments, Worcestershire, UK). For heavy metal analysis, recoveries varied but all fell within the range of 76-95\%. The precision was nearly $8 \%$ with a confidence level of $95 \%$.

\section{Results}

\section{1. $R D S$ grain size distribution}

The cumulative particle volume distribution curves of the RDS grain size from three land use types were similar (Fig. 2). There was a slight difference in the cumulative percentage of the grain size, with main traffic roads $>$ college and resident avenues $>$ urban village roads. The median diameter of RDS $d_{50}$ in the three land use types ranged from 100 to $200 \mu \mathrm{m}$. Our results showed that the RDS particles from all three land use types were predominantly
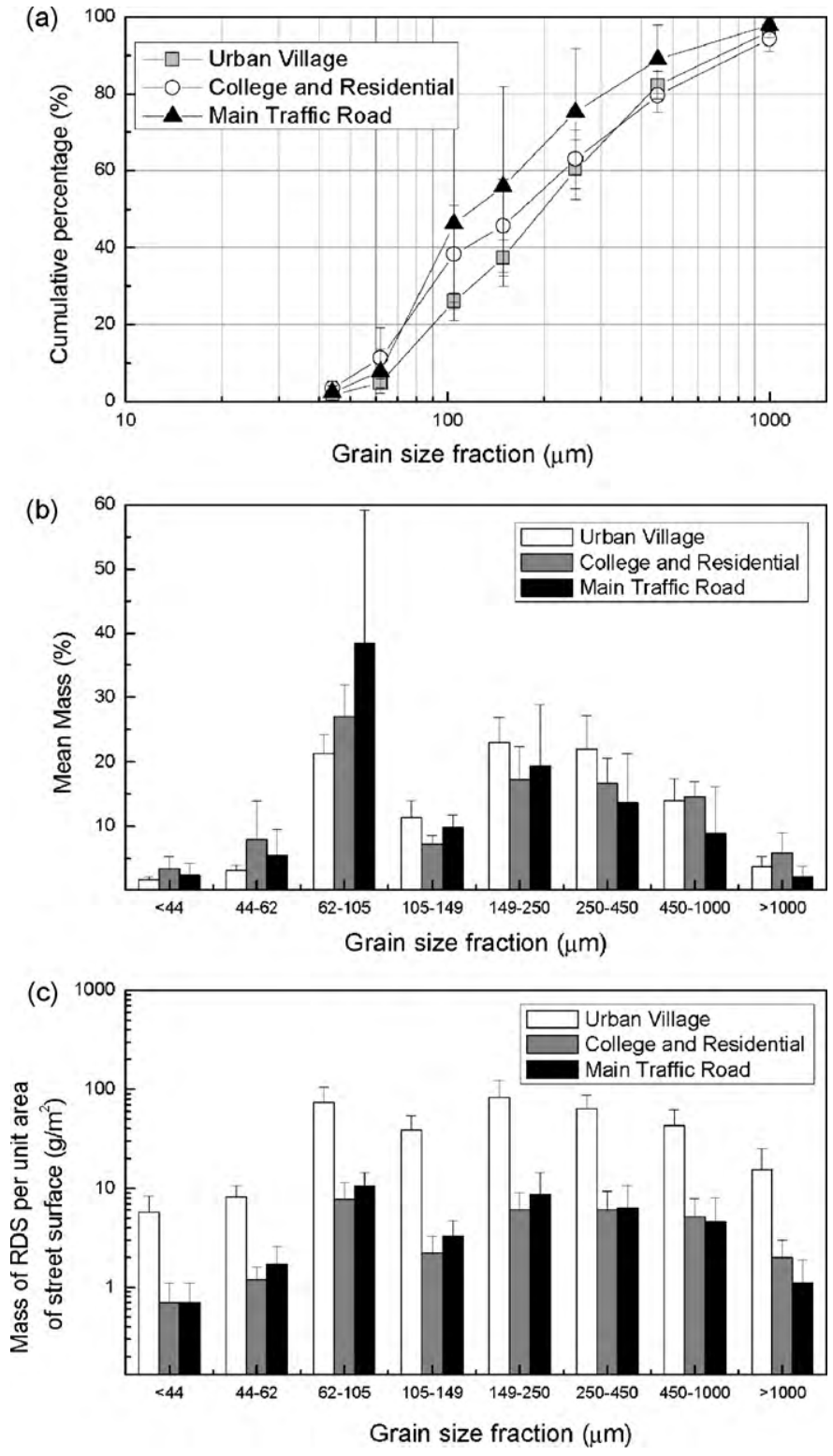

Fig. 2. (a) Grain size distribution of road-deposited sediment, (b) histogram of mean mass percentages of road-deposited sediment versus grain size fraction and (c) roaddeposited sediment mass per unit area of different urban land uses versus grain size fraction. $\log _{10}$ value is used as arithmetic scaling of the $Y$-axis in Fig. 2c. Values expressed as mean \pm standard deviation.

fine particles ( $<250 \mu \mathrm{m}, 60-75 \%)$. A histogram of the mean mass percentages versus the grain size fraction is shown in Fig. 2b. RDS particles with grain sizes of $62-105 \mu \mathrm{m}$ were the most abundant among the eight size fractions, accounting for $27 \pm 5 \%$ and $38 \pm 21 \%$ of the RDS from college and residential areas and main traffic roads, respectively. The three highest mass fractions of RDS particles collected from urban village areas were as follows: $62-105 \mu \mathrm{m}$, $21 \pm 3 \%$; $149-250 \mu \mathrm{m}, 22 \pm 8 \% ; 250-450 \mu \mathrm{m}, 23 \pm 5 \%$. Urban village areas had the highest RDS mass values per unit area among all grain size fractions (Fig. 2c). These findings can be attributed to the infrequency of the street sweeping and the low removal efficiency of the street sweepers in these urban village areas. Our on-site investigation indicated that these urban village areas were seldom swept. We also found that the road-surface condition influenced the efficiency of sweeping because the street surfaces in urban village areas were broken and rough, resulting in increased storage of finer materials. 
$\square$ Urban Village $\square$ College and Residental $\square$ Main Traffic RoadSEL: Severe effect level; LEL: Lowest effect level
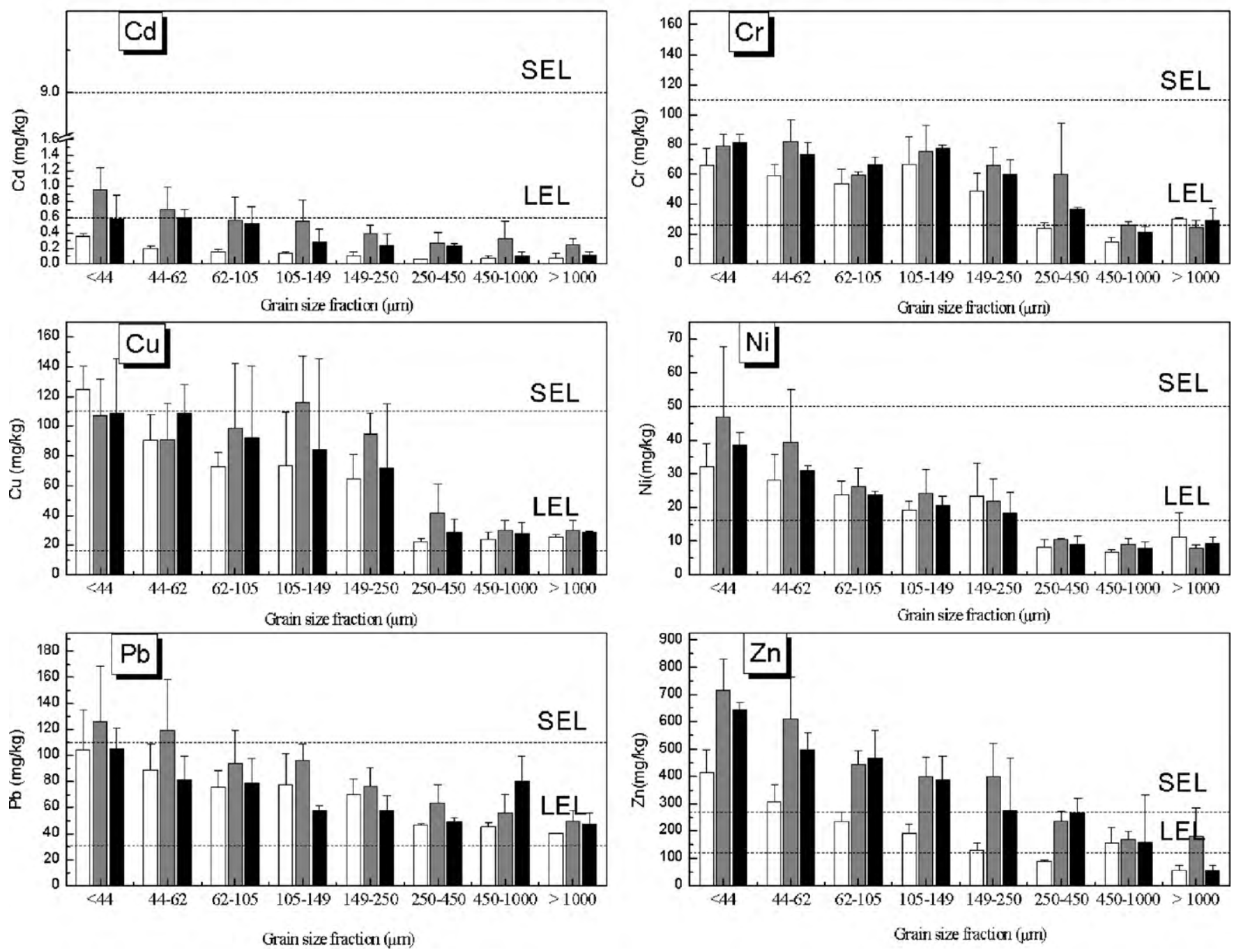

Fig. 3. Heavy metal concentrations in RDS (SEL: severe effect level; LEL: lowest effect level). Values expressed as mean \pm standard deviation.

\subsection{Heavy metal concentrations of RDS}

We measured six metals ( $\mathrm{Cd}, \mathrm{Cr}, \mathrm{Cu}, \mathrm{Ni}, \mathrm{Pb}$ and $\mathrm{Zn}$ ) in each grain size fraction (Fig. 3) and found the highest metal concentrations in the $<44 \mu \mathrm{m}$ fraction, with the exception of $\mathrm{Cd}$ and $\mathrm{Cu}$ in the main traffic roads and $\mathrm{Cr}$ in the college and residential areas, for which the highest concentrations were observed in the 44-62 $\mu \mathrm{m}$ fraction. Generally, smaller grain size fractions had higher heavy metal concentration. The heavy metal concentration was lowest in the $250-2000 \mu \mathrm{m}$ fraction at all sites, with the exception of $\mathrm{Pb}$, which was highest in the $450-1000 \mu \mathrm{m}$ fraction on the main traffic roads. Zinc was the most abundant element in the various size fractions at all areas. Our results indicate the importance of removing fine particles from RDS during street sweeping.

We applied the lowest screening effect levels (LEL) and severe effect screening levels (SEL) [31] to assess the heavy metal pollution in RDS (Fig. 3). If the LEL is exceeded, the metal may have a moderate impact on biota health, while if the SEL is exceeded, the metal may severely impact biota health [32]. Our results showed that the $\mathrm{Cu}$ and $\mathrm{Pb}$ in each size fraction and $\mathrm{Cr}, \mathrm{Ni}$ and $\mathrm{Zn}$ in RDS with a diameter $<250 \mu \mathrm{m}$ exceeded the LEL. The percent exceedance of SEL for $\mathrm{Cu}$,
$\mathrm{Ni}, \mathrm{Pb}, \mathrm{Zn}$ was about $18 \%, 1 \%, 10 \%, 50 \%$ for all size fraction of RDS respectively.

\subsection{Heavy metal loads of RDS by different land use types}

It is helpful to estimate the heavy metal loads of RDS with different grain size ranges to assess the impact of storm water pollution and to improve the existing street cleaning methods. Our results revealed high variations in the heavy metal loads among impervious surfaces of different urban land uses (Fig. 4). The metal load for each fraction in urban village areas was approximately three to thirteen times higher than in college and residential areas, and 5-14 times higher than in main traffic roads areas. We also estimated the metal loads and the contribution of each grain size fraction

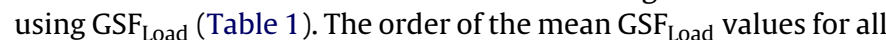
metals combined was $62-105 \mu \mathrm{m} \quad(34 \pm 12 \%)>149-250 \mu \mathrm{m}$ $(21 \pm 9 \%)>105-149 \mu \mathrm{m} \quad(11 \pm 4 \%)>250-450 \mu \mathrm{m}$ $(11 \pm 5 \%)>44-62 \mu \mathrm{m}(8 \pm 6 \%)>450-1000 \mu \mathrm{m}(6 \pm 4 \%)>0-44 \mu \mathrm{m}$ $(4 \pm 3 \%)>1000-2000 \mu \mathrm{m}(2 \pm 2 \%)$. Heavy metals in RDS were mainly stored in the $<250 \mu \mathrm{m}$ fraction $(80 \%)$. The street sweeper efficiency was characterized by a decreasing trend with decreasing grain size, which implies that it is difficult to remove $80 \%$ of the 
Urban Village $\square$ College and Residental $\square$ Main Traffic Road
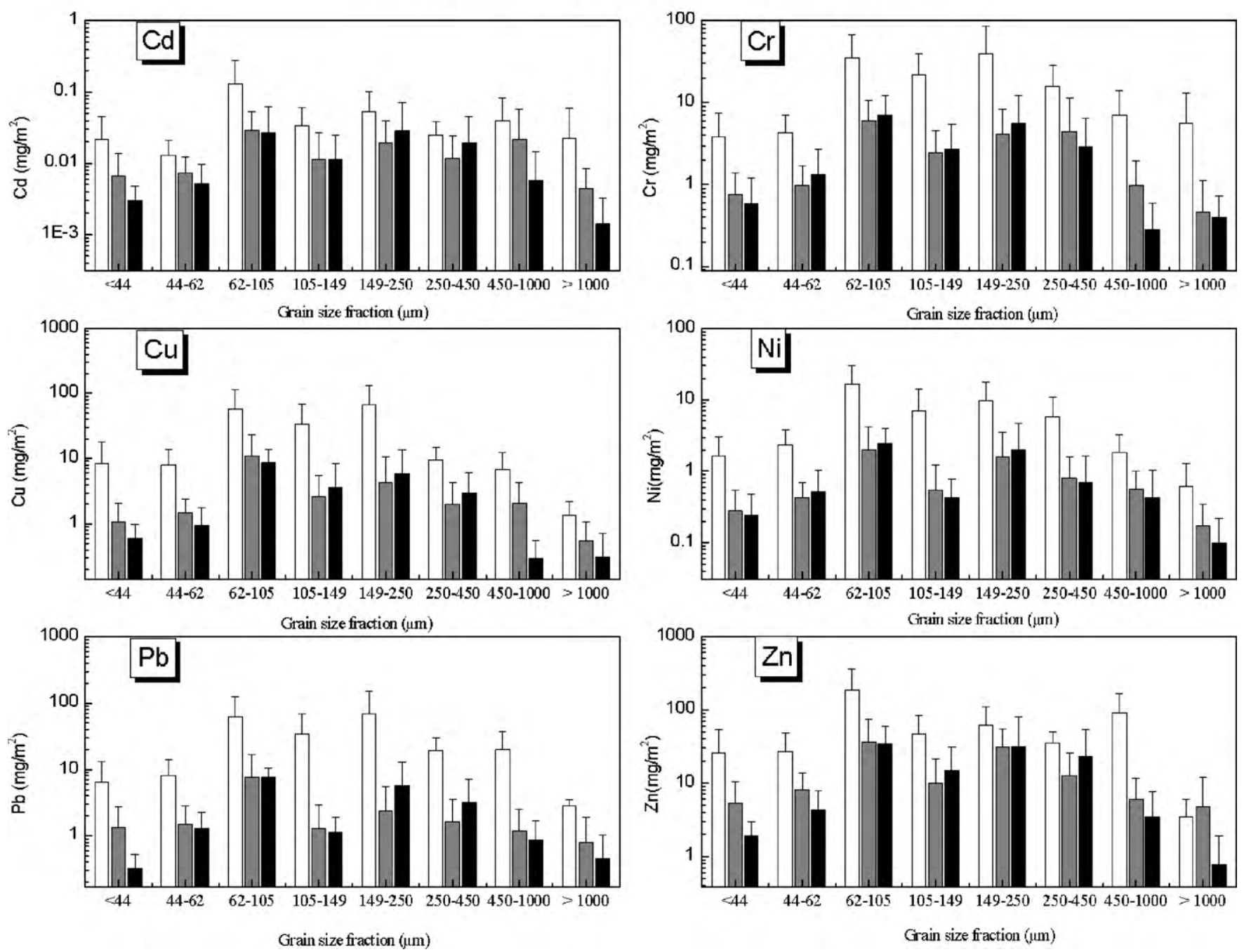

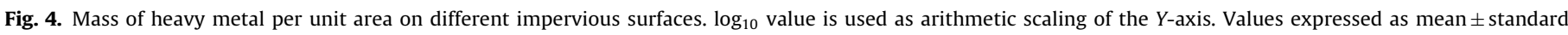
deviation.

metal load by conventional street sweepers because it is stored in the $<250 \mu \mathrm{m}$ fraction $[33,34]$.

\subsection{Total suspended solids and heavy metal contents in urban runoff water}

Surface runoff is the major pathway of heavy metals to receiving water in urban areas. Our results showed that heavy metal pollutants in runoff water were primarily in particulate form. Specifically, the particulate heavy metals in the runoff water accounted for $54.5 \%, 44.3 \%, 59.0 \%, 63.3 \%$, and $82.0 \%$ of the total $\mathrm{Cr}$, total $\mathrm{Cu}$, total $\mathrm{Ni}$, total $\mathrm{Pb}$ and total $\mathrm{Zn}$, respectively, during the two rainfall events. These findings imply that RDS made a great contribution to particulate pollutants in urban runoff.

The TSS content in runoff water was proportional to the mass RDS per unit area in the three land use types. The parti-

Table 1

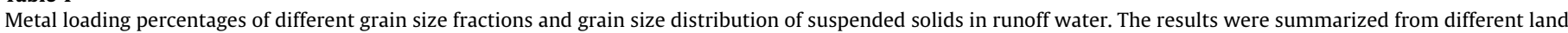
use types ${ }^{\mathrm{a}}$.

\begin{tabular}{|c|c|c|c|c|c|c|c|c|}
\hline \multirow[t]{2}{*}{ Grain size fraction $(\mu \mathrm{m})$} & \multicolumn{6}{|c|}{ Metal loading percentages of different grain size fractions/GSF $\mathrm{Laad}_{(\%)}$} & \multicolumn{2}{|c|}{$\begin{array}{l}\text { Grain size partitioning in } \\
\text { runoff water }(\%)\end{array}$} \\
\hline & $\mathrm{Cd}$ & $\mathrm{Cr}$ & $\mathrm{Ni}$ & $\mathrm{Cu}$ & $\mathrm{Zn}$ & $\mathrm{Pb}$ & $0-15 \min$ & $15-45 \mathrm{~min}$ \\
\hline$<44$ & $5.5 \pm 1.7$ & $3.3 \pm 1.5$ & $5.2 \pm 2.8$ & $4.1 \pm 2.7$ & $4.3 \pm 1.8$ & $4.0 \pm 3.2$ & $71 \pm 15$ & $755 \pm 11$ \\
\hline 44-62 & $8.3 \pm 2.8$ & $6.5 \pm 2.1$ & $10 \pm 5.5$ & $7.4 \pm 5.2$ & $7.9 \pm 1.9$ & $7.8 \pm 4.1$ & $6.7 \pm 2.9$ & $6.4 \pm 3.6$ \\
\hline 62-105 & $33 \pm 23$ & $31 \pm 28$ & 35. \pm 23 & $38 \pm 15$ & $34 \pm 24$ & $32 \pm 21$ & $7.3 \pm 3.7$ & $6.5 \pm 4.1$ \\
\hline $105-149$ & $15 \pm 1.2$ & $20 \pm 1.3$ & $17 \pm 1.1$ & $16 \pm 5.8$ & $16 \pm 0.4$ & $15 \pm 1.4$ & $3.1 \pm 2.1$ & $2.5 \pm 1.6$ \\
\hline $149-250$ & $20 \pm 15$ & $25 \pm 19$ & $22 \pm 18$ & $20 \pm 11$ & $21 \pm 18$ & $19 \pm 12$ & $2.7 \pm 1.9$ & $2.0 \pm 1.5$ \\
\hline $250-450$ & $11 \pm 6.7$ & $11 \pm 7.0$ & $8.9 \pm 6.3$ & $9.5 \pm 3.3$ & $13 \pm 9.6$ & $14 \pm 6.6$ & $1.9 \pm 1.7$ & $1.2 \pm 1.5$ \\
\hline 450-1000 & $8.3 \pm 3.6$ & $4.9 \pm 6.0$ & $5.1 \pm 4.4$ & $6.2 \pm 2.9$ & $6.5 \pm 0.0$ & $8.59 \pm 3.8$ & $3.9 \pm 3.6$ & $3.1 \pm 2.2$ \\
\hline$>1000$ & $2.3 \pm 0.8$ & $2.7 \pm 1.1$ & $1.9 \pm 0.8$ & $2.1 \pm 0.6$ & $2.1 \pm 0.5$ & $2.6 \pm 1.0$ & $3.3 \pm 5.8$ & $3.2 \pm 3.6$ \\
\hline
\end{tabular}

a Values expressed as mean \pm standard deviation. 
Table 2

Event mean concentration (EMC) of total suspended sediment (TSS) and total heavy metal contents in runoff water during two rainfall events.

\begin{tabular}{|c|c|c|c|c|c|c|c|c|c|}
\hline Date of rain event & Land use types & Metal forms & $\mathrm{Cd}(\mu \mathrm{g} / \mathrm{L})$ & $\mathrm{Cr}(\mathrm{mg} / \mathrm{L})$ & $\mathrm{Cu}(\mathrm{mg} / \mathrm{L})$ & $\mathrm{Ni}(\mathrm{mg} / \mathrm{L})$ & $\mathrm{Pb}(\mathrm{mg} / \mathrm{L})$ & $\mathrm{Zn}(\mathrm{mg} / \mathrm{L})$ & TSS (mg/L) \\
\hline \multirow[t]{6}{*}{$6 / 16 / 2009$} & \multirow[t]{2}{*}{ Urban villages } & Dissolved & 0.009 & 0.008 & 0.021 & 0.013 & 0.017 & 0.061 & $N / A^{a}$ \\
\hline & & Total & 0.201 & 0.010 & 0.058 & 0.018 & 0.064 & 0.399 & 1085 \\
\hline & \multirow[t]{2}{*}{ College and residential areas } & Dissolved & 0.107 & 0.007 & 0.050 & 0.009 & 0.022 & 0.046 & $\mathrm{~N} / \mathrm{A}$ \\
\hline & & Total & 0.217 & 0.046 & 0.066 & 0.038 & 0.074 & 0.219 & 274 \\
\hline & \multirow[t]{2}{*}{ Main traffic roads } & Dissolved & 0.089 & 0.046 & 0.026 & 0.009 & 0.030 & 0.076 & $\mathrm{~N} / \mathrm{A}$ \\
\hline & & Total & 0.222 & 0.060 & 0.039 & 0.040 & 0.079 & 0.470 & 437 \\
\hline \multirow[t]{6}{*}{$6 / 18 / 2009$} & \multirow[t]{2}{*}{ Urban villages } & Dissolved & 0.045 & 0.010 & 0.021 & 0.010 & 0.033 & 0.043 & $\mathrm{~N} / \mathrm{A}$ \\
\hline & & Total & 0.138 & 0.049 & 0.038 & 0.041 & 0.077 & 0.201 & 774 \\
\hline & \multirow[t]{2}{*}{ College and residential areas } & Dissolved & 0.123 & 0.030 & 0.021 & 0.013 & 0.035 & 0.067 & $\mathrm{~N} / \mathrm{A}$ \\
\hline & & Total & 0.315 & 0.066 & 0.044 & 0.038 & 0.081 & 0.264 & 156 \\
\hline & \multirow[t]{2}{*}{ Main traffic roads } & Dissolved & 0.147 & 0.006 & 0.042 & 0.009 & 0.025 & 0.029 & $\mathrm{~N} / \mathrm{A}$ \\
\hline & & Total & 0.323 & 0.009 & 0.080 & 0.013 & 0.063 & 0.341 & 315 \\
\hline
\end{tabular}

a Not available.

Table 3

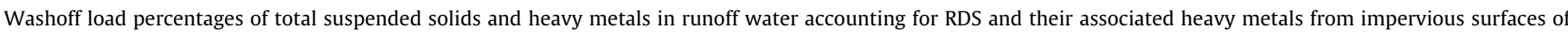
different land use types during two rainfall events (\%).

\begin{tabular}{|c|c|c|c|c|c|c|c|c|}
\hline Date of rain event & Land use types & $\mathrm{Cd}$ & $\mathrm{Cr}$ & $\mathrm{Cu}$ & $\mathrm{Ni}$ & $\mathrm{Pb}$ & $\mathrm{Zn}$ & TSS \\
\hline \multirow[t]{3}{*}{$6 / 16 / 2009$} & Urban village & 0.2 & 0.0 & 0.4 & 0.2 & 0.4 & 1.4 & 6.6 \\
\hline & College and residential & 3.0 & 3.9 & 1.3 & 9.1 & 5.9 & 3.0 & 17.7 \\
\hline & Main traffic road & 4.2 & 2.5 & 1.1 & 9.0 & 4.8 & 6.8 & 23.0 \\
\hline \multirow[t]{3}{*}{$6 / 18 / 2009$} & Urban village & 1.0 & 1.2 & 0.4 & 2.7 & 0.8 & 1.3 & 9.4 \\
\hline & College and residential & 8.4 & 7.2 & 3.6 & 15.7 & 10.4 & 6.9 & 10.0 \\
\hline & Main traffic road & 4.2 & 0.6 & 6.5 & 2.3 & 7.4 & 10.8 & 34.2 \\
\hline
\end{tabular}

cles $<44 \mu \mathrm{m}$ were the primary component of runoff, contributing to more than $70 \%$ of the TSS (Table 1 ). These findings suggest that particles $<44 \mu \mathrm{m}$ comprised the critical size fraction that contributed to heavy metal pollution caused by urban runoff. However, the variation in TSS among different land use types was not proportional to the variation in total metal contents (Table 2). For example, the TSS in runoff water from urban villages was greatest among the three land use types, but the concentrations of most heavy metals were not necessarily the highest values. TSS and particulate heavy metals in runoff water accounted for $16.8 \%, 2.6 \%, 2.2 \%, 6.5 \%, 5.0 \%$, and $5.1 \%$ of the RDS, total $\mathrm{Cr}$, total $\mathrm{Cu}$, total $\mathrm{Ni}$, total $\mathrm{Pb}$ and total $\mathrm{Zn}$, respectively (Table 3).

\section{Discussion}

The heavy metal contents in RDS play an important role in urban runoff pollution. However, the contents of heavy metals in RDS have been found to have high variation among different particle grain sizes and different cities worldwide (Table 4). The RDS grain size distribution also has a significant effect on mediating transport and chemical interactions [26]. An important index of contamination

Table 4

Comparison of heavy metal contents in RDS among Beijing and other cities worldwide (unit of heavy metal contents: mg/kg, and unit of grain size GS: $\mu \mathrm{m}$ ).

\begin{tabular}{|c|c|c|c|c|c|c|c|c|}
\hline City & $\mathrm{Cd}$ & $\mathrm{Cr}$ & $\mathrm{Cu}$ & $\mathrm{Ni}$ & $\mathrm{Pb}$ & $\mathrm{Zn}$ & GS & Ref. $^{a}$ \\
\hline Hong Kong & 3.77 & $\mathrm{~N} / \mathrm{A}$ & 173 & $\mathrm{~N} / \mathrm{A}$ & 181 & 1450 & $<2000$ & [35] \\
\hline Aviles (N. Spain) & 22.3 & 41.6 & 183 & 27.5 & 514 & 4892 & $<147$ & [36] \\
\hline London & $0.96-4.91$ & N/A & $19-312$ & N/A & $245-6190$ & $100-539$ & $<600$ & [37] \\
\hline Hawaii & $\mathrm{N} / \mathrm{A}^{\mathrm{b}}$ & $\mathrm{N} / \mathrm{A}$ & 167 & $\mathrm{~N} / \mathrm{A}$ & 106 & 434 & $<125$ & [38] \\
\hline Bursa, Turkey & 3.1 & N/A & $\mathrm{N} / \mathrm{A}$ & $\mathrm{N} / \mathrm{A}$ & 210 & 57 & $<200$ & [39] \\
\hline New York & 8 & $\mathrm{~N} / \mathrm{A}$ & 355 & $\mathrm{~N} / \mathrm{A}$ & 2583 & 1811 & $<963$ & [40] \\
\hline \multirow[t]{6}{*}{ Gela, Sicily, Italy } & N/A & $14-43$ & $15-355$ & $14-30$ & $7-54$ & $42-373$ & $500-250$ & [40] \\
\hline & N/A & $15-88$ & $12-296$ & $14-47$ & $7-265$ & $45-499$ & $250-125$ & \\
\hline & $\mathrm{N} / \mathrm{A}$ & $21-90$ & $31-442$ & $22-70$ & $26-189$ & $120-412$ & $125-63$ & \\
\hline & N/A & 27-109 & $42-300$ & $26-75$ & $34-185$ & $187-576$ & $63-40$ & \\
\hline & N/A & $19-100$ & $42-226$ & $30-78$ & $32-174$ & $187-802$ & $40-20$ & \\
\hline & $\mathrm{N} / \mathrm{A}$ & $11-61$ & $39-152$ & $31-64$ & $30-155$ & $156-703$ & $<20$ & \\
\hline \multirow[t]{8}{*}{ Beijing } & 0.1 & 28.0 & 28.0 & 9.6 & 45.9 & 98.7 & $>1000$ & This article \\
\hline & 0.2 & 20.4 & 27.3 & 7.9 & 60.3 & 162 & $1000-450$ & \\
\hline & 0.2 & 40.3 & 30.9 & 9.3 & 53.0 & 197 & $450-250$ & \\
\hline & 0.3 & 58.1 & 77.2 & 21.1 & 68.0 & 268 & $250-149$ & \\
\hline & 0.3 & 73.3 & 91.2 & 21.4 & 77.2 & 327 & 149-105 & \\
\hline & 0.4 & 60.0 & 87.9 & 24.6 & 82.9 & 383 & $105-62$ & \\
\hline & 0.5 & 71.2 & 96.8 & 32.9 & 96.3 & 471 & $62-44$ & \\
\hline & 0.6 & 75.5 & 113 & 39.2 & 112 & 591 & $<44$ & \\
\hline
\end{tabular}

\footnotetext{
a References.
}

b N/A: not available. 
for RDS is the mass load of a heavy metal in a given grain size fraction [7]. Sutherland reported that particles with a grain size $<63 \mu \mathrm{m}$ were the single most important mass component, with $38 \% \mathrm{~Pb}$ of the total sediment being stored in this fraction [2]. In our study, we found that the $62-105 \mu \mathrm{m}$ fraction had the greatest influence on the overall contamination of the RDS. Our results also indicate the importance of removing fine particles from RDS during street sweeping.

RDS makes a great contribution to the runoff pollutant loads [41-43], and the size of the RDS is a critical factor affecting the mobility of pollutants and the efficiency of their removal. The behavior of RDS in runoff depends on its grain size distribution $[11,44]$. Storm runoff selectively transports fine particles from road surfaces, and these particles tend to contain higher trace element concentrations $[2,13]$. Roger et al. reported that $77.8 \%$ of the suspended solids in runoff consisted of particles with diameters lower than $50 \mu \mathrm{m}$ [13]. Kim and Sansalone reported that suspended solids with a grain size $<75 \mu \mathrm{m}$ accounted for $25-80 \%$ of the total suspended solids in runoff [26]. In the present study, we found that suspended solids with a grain size $<44 \mu \mathrm{m}$ in runoff water accounted for more than $70 \%$ of the particles in suspended solids in Beijing, while other sized fractions contributed less than $30 \%$.

It is important to understand RDS transport and fate to enable development of appropriate strategies for management of urban non-point source pollution. Previously, it was reported that a large proportion of the heavy metals were associated with coarser particles that had lower mobility [45]. In this study, the two events sampled are close together in time, and the lower fluxes (TSS $\mathrm{mg} / \mathrm{L}$ ) on June 18 (Table 2 ) are reflective of a depleted road-surface storage component. The results of the present study suggested that the suspended solids in runoff water accounted for $17 \%$ of the RDS, while the particulate heavy metal loads in the runoff water accounted for less than $7 \%$.

\section{Conclusions}

Our results implied that the RDS grain size distribution was the key factor involved in determining the particle mobility and its associated heavy metal load. RDS with a smaller grain size had higher metal contents, whereas particles with smaller grain size $(<250 \mu \mathrm{m})$ were critical to carrying heavy metals in RDS, which contributed more than $80 \%$ of the total metal loads found in the RDS washoff.

The metals in runoff water are primarily in particulate form. We found that storm runoff selectively transported RDS with different grain sizes. Specifically, suspended solids with a grain size of $<44 \mu \mathrm{m}$ accounted for more than $70 \%$ of the particles in runoff water, while particles of other grain sizes contributed less than $30 \%$. The TSS in the runoff water accounted for about $20 \%$ of RDS. The heavy metal content in the TSS was $2.2-6.5 \%$ of that of the RDS.

Impervious surface types of different urban land uses played an important role in accumulating the RDS and metal contents in RDS, which affected the TSS and metal concentration in the runoff water. Of the three land use types in our study, urban villages had the highest amount of RDS per unit area and the highest TSS content in runoff water, but the lowest metal contents in RDS. The concentrations of metals in runoff water, which were determined based on the mass of the suspended solid in runoff water and their associated metal contents in RDS, were at similar levels among the three land use types.

\section{Acknowledgments}

This work was supported by the National Natural Science Foundation of China (No. 40971271), One Hundred Talents Program of
The Chinese Academy of Sciences and the Key Project of Water Pollution Control and Management of China (No. 2008ZX07101006-08). We thank Lina Wang and Shuxia He for their help collecting urban storm water samples.

\section{References}

[1] H. Zhao, C. Yin, M. Chen, W. Wang, Runoff pollution impacts of polycyclic aromatic hydrocarbons in street dusts from a stream network town, Water Sci. Technol. 58 (2008) 2069-7076.

[2] R.A. Sutherland, Lead in grain size fractions of road-deposited sediment, Environ. Pollut. 121 (2003) 229-237.

[3] K. Adachi, Y. Tainosho, Single particle characterization of size-fractionated road sediments, Appl. Geochem. 20 (2005) 849-859.

[4] S. Charlesworth, M. Everett, R. McCarthy, A. Ordonez, E. de Miguel, A comparative study of heavy metal concentration and distribution in deposited street dusts in a large and a small urban area: Birmingham and Coventry, West Midlands, UK, Environ. Int. 29 (2003) 563-573.

[5] J.N. Brown, B.M. Peake, Sources of heavy metals and polycyclic aromatic hydrocarbons in urban stormwater runoff, Sci. Total Environ. 359 (2006) 145-155.

[6] C.B. Gardner, A.E. Carey, Trace metal and major ion inputs into the Olentangy River from an urban storm sewer, Environ. Sci. Technol. 38 (2004) 5319-5326.

[7] W. Zhu, B. Bian, L. Li, Heavy metal contamination of road-deposited sediments in a medium size city of China, Environ. Monit. Assess. 147 (2008) 171-181.

[8] H. Zhao, C. Yin, M. Chen, W. Wang, Risk assessment of heavy metals in street dust particles to a stream network, Soil Sediment Contam. 18 (2009) 173-183.

[9] B. Bian, W. Zhu, Particle size distribution and pollutants in road-deposited sediments in different areas of Zhenjiang, China, Environ. Geochem. Health 31 (2009) 511-520.

[10] A. Deletic, D.W. Orr, Pollution buildup on road surfaces, J. Environ. Eng. 131 (2005) 49-59.

[11] H. Furumai, H. Balmer, M. Boller, Dynamic behavior of suspended pollutants and particle size distribution in highway runoff, Water Sci. Technol. 46 (2002) 413-418.

[12] R.K. Aryal, H. Furumai, F. Nakajima, M. Boller, Dynamic behavior of fractional suspended solids and particle-bound polycyclic aromatic hydrocarbons in highway runoff, Water Res. 39 (2005) 5126.

[13] S. Roger, M. Montrejaud-Vignoles, M.C. Andral, L. Herremans, J.P. Fortune, Mineral, physical and chemical analysis of the solid matter carried by motorway runoff water, Water Res. 32 (1998) 1119.

[14] M.C. Andral, S. Roger, M. Montrejaud-Vignoles, L. Herremans, Particle size distribution and hydrodynamic characteristics of solid matter carried by runoff from motorways, Water Environ. Res. (1999) 398-407.

[15] H. Zhao, C. Yin, M. Chen, W. Wang, J. Chris, B. Shan, Size distribution and diffuse pollution impacts of PAHs in street dust in urban streams in the Yangtze River Delta, J. Environ. Sci. 21 (2009) 162-167.

[16] J. German, G. Svensson, Metal content and particle size distribution of street sediments and street sweeping waste, Water Sci. Technol. 46 (2002) 191-198.

[17] M. Viklander, Particle size distribution and metal content in street sediments, J. Environ. Eng. 124 (1998) 761-766.

[18] J.A. Sartor, D.R. Gaboury, Street sweeping as a water pollution control measure: lessons learned over the past ten years, Sci. Total Environ. 33 (1984) 171-183.

[19] Y.M. Chang, C.M. Chou, K.T. Su, C.H. Tseng, Effectiveness of street sweeping and washing for controlling ambient TSP, Atmos. Environ. 39 (2005) 1891-1902.

[20] J.D. Sartor, G.B. Boyd, F.J. Agardy, Water pollution aspects of street surface contaminants, J. Water Pollut. Control Fed. (1974) 458-467.

[21] G.M. Bender, M.L. Terstriep, Effectiveness of street sweeping in urban runoff pollution control, Sci. Total Environ. 33 (1984) 185-192.

[22] L. Herngren, A. Goonetilleke, G.A. Ayoko, Analysis of heavy metals in roaddeposited sediments, Anal. Chim. Acta 571 (2006) 270-278.

[23] X. Lu, L. Wang, K. Lei, J. Huang, Y. Zhai, Contamination assessment of copper, lead, zinc, manganese and nickel in street dust of Baoji, NW China, J. Hazard. Mater. 161 (2009) 1058-1062.

[24] M.C. Gromaire-Mertz, S. Garnaud, A. Gonzalez, G. Chebbo, E. Brelot, Characterisation of urban runoff pollution in Paris, Water Sci. Technol. 39 (1999) $1-8$.

[25] L.Q. Li, C.Q. Yin, Q.C. He, L.L. Kong, First flush of storm runoff pollution from an urban catchment in China, J. Environ. Sci. 19 (2007) 295-299.

[26] J.Y. Kim, J.J. Sansalone, Event-based size distributions of particulate matter transported during urban rainfall-runoff events, Water Res. 42 (2008) 2756-2768.

[27] M. Murakami, F. Nakajima, H. Furumai, Modelling of runoff behaviour of particle-bound polycyclic aromatic hydrocarbons (PAHs) from roads and roofs, Water Res. 38 (2004) 4475-4483.

[28] J.J. Sansalone, S.G. Buchberger, Partitioning and first flush of metals in urban roadway storm water, J. Environ. Eng. 123 (1997) 134-143.

[29] L.S. Clesceri, A.E. Greenberg, A.D. Eaton, American Public Health Association, American Water Works Association, and Water Environment Federation, in: Standard Methods for the Examination of Water and Wastewater, 20th, 1998.

[30] A. Tessier, P.G.C. Campbell, M. Bisson, Sequential extraction procedure for the speciation of particulate trace metals, Anal. Chem. 51 (1979) 844-851.

[31] NYSDEC, Technical Guidance for Screening Contaminated Sediments, New York State Department of Environmental Conservation, Department of Fish, Wildlife and Marine Resources, Albany, NY, 1999. 
[32] J.R. Graney, T.M. Eriksen, Metals in pond sediments as archives of anthropogenic activities: a study in response to health concerns, Appl. Geochem. 19 (2004) 1177-1188.

[33] J.D. Sartor, G.B. Boyd, Water Pollution Aspects of Street Surface Contaminants, Report EPA-R2-72-081, US EPA Office of Research and Monitoring, Washington, DC, 1972.

[34] R. Pitt, Demonstration of Nonpoint Pollution Abatement through Improved Street Cleaning Practices, EPA-600/2-79-161, U.S. Environmental Protection Agency, Cincinnati, OH, 1979.

[35] X.D. Li, C.S. Poon, P.S. Liu, Heavy metal contamination of urban soils and street dusts in Hong Kong, Appl. Geochem. 16 (2001) 1361-1368.

[36] A. Ordonez, J. Loredo, E. De Miguel, S. Charlesworth, Distribution of heavy metals in the street dusts and soils of an industrial city in northern Spain, Arch. Environ. Contam. Toxicol. 44 (2003) 160-170.

[37] R.M. Harrison, D.P.H. Laxen, S.J. Wilson, Chemical association of lead, cadmium, copper, and zinc in street dust and roadside soil, Environ. Sci. Technol. 15 (1981) 1378-1383.

[38] R.A. Sutherland, C.A. Tolosa, Multi-element analysis of road-deposited sediment in an urban drainage basin, Honolulu, Hawaii, Environ. Pollut. 110 (2000) 483-495.
[39] H. Arslan, Heavy metals in street dust in Bursa, Turkey, J. Trace Microprobe Tech. 19 (2001) 439-445.

[40] J.E. Fergusson, N.D. Kim, Trace elements in street and house dusts: sources and speciation, Sci. Total Environ. 100 (1991) 125-150.

[41] W.J. Walker, R.P. McNutt, C.K. Maslanka, The potential contribution of urban runoff to surface sediments of the Passaic River: sources and chemical characteristics, Chemosphere 38 (1999) 363-377.

[42] V. Rocher, S. Azimi, R. Moilleron, G. Chebbo, Hydrocarbons and heavy metals in the different sewer deposits in the Te Marais' catchment (Paris, France): stocks, distributions and origins, Sci. Total Environ. 323 (2004) 107-122.

[43] M. Stone, I.G. Droppo, Distribution of lead, copper and zinc in size-fractionated river bed sediment in two agricultural catchments of southern Ontario, Canada, Environ. Pollut. 93 (1996) 353-362.

[44] M. Murakami, F. Nakajima, H. Furumai, Size- and density-distributions and sources of polycyclic aromatic hydrocarbons in urban road dust, Chemosphere 61 (2005) 783-791.

[45] M. Stone, J. Marsalek, Trace metal composition and speciation in street sediment: Sault Ste Marie, Canada, Water Air Soil Pollut. 87 (1996) 149-169. 